\title{
PENDIDIKAN FULL DAY SCHOOL DALAM PERSPEKTIF EPISTEMOLOGI MUHAMMAD ‘ABID AL- JABIRI
}

\author{
Hasan Baharun \\ Universitas Nurul Jadid Paiton Probolinggo \\ Email: ha54nbaharun@gmail.com \\ Saudatul Alawiyah \\ Universitas Nurul Jadid Paiton Probolinggo \\ Email: uunune22@gmail.com
}

\begin{abstract}
This paper presents about full day school education in the epistemology perspective of Muhammad 'Abid Al-Jabiri. Muhammad 'Abid Al-Jabiri is one of contemporary Islamic thinkers with the theories of bayani, irfani and burhani. Where the theory of epistemology serve is a science that comes from a sacred text and the theory of irfani epistemology derived from intuition while the theory of burhani epistemology derived from the principles of logic, ratio and reason. And this paper examines the education of full day school with the theories of bayani, 'irfani and burhani. With the hope of third theory can be understood as effort to build and create paradigm of society about policy of full day school, so from various problematic causing the pros and cons to full day school concept which have been published by Mendikbud can be overcome.
\end{abstract}

Keyword: full day school, Islamic epistemology

\section{A. Pendahuluan}

Pendidikan memiliki peran yang sangat penting dalam kehidupan manusia. ${ }^{1}$ Dalam prakteknya, dari tahun ke tahun potret dunia pendidikan di Indonesia seringkali dan bahkan selalu saja diwarnai dengan perubahan kebijakan, mulai dari perubahan kurikulum, hingga perubahan sistem pembelajaran sebagai upaya mewujudkan harapan setiap oknum pendidikan, sehingga Menteri Pendidikan Nasional menggagas adanya sistem Full Day School.

Di Indonesia, wacana Full Day School (FDS) yang diusulkan Menteri Pendidikan Nasional Muhadjir Efendy mengundang pro dan kontra, karena full day

1 Hasan Baharun, "Total Moral Quality: A New Approach for Character Education in Pesantren,” Ulumuna 21, no. 1 (2017): 57-80. 
Hasan Baharun, Saudatul Alawiyah: Pendidikan Full Day School...

school dianggap sebagai model atau sistem pendidikan baru, padahal sudah sejak lama model tersebut digunakan, bahkan di Amerika Serikat telah diterapkan sejak tahun 1980-an, ${ }^{2}$ sehingga sampai saat ini sistem pendidikan di Indonesia belum merata.

Dalam hal ini, pihak yang pro mengatakan dengan adanya FDS dapat membantu orang tua yang bekerja, artinya orang tua dapat fokus dalam bekerja, sedangkan kegiatan anak dapat terkontrol di sekolah. Saat ini memang banyak sekolah menawarkan kurikulum FDS bahkan dalam bentuk sekolah berasrama atau disebut juga boarding school. Kegiatan siswa selama 24 jam dapat dipantau pihak sekolah. Faktanya, banyak orang tua yang berminat menyekolahkan anaknya ke sekolah yang berbasis boarding school walau harus membayar mahal. ${ }^{3}$ Selain itu, beberapa kelebihan FDS adalah; peserta didik mendapat metode pembelajaran yang bervariasi dibanding sekolah regular, begitu juga dalam aspek perkembangan minat, bakat, dan kecerdasan peserta didik terekam sejak dini melalui pantauan program bimbingan dan konseling serta meningkatkan gengsi orangtua yang memiliki orientasi terhadap hal-hal yang bersifat prestisius. $^{4}$

Tidak hanya itu, berdasarkan data hasil penelitian yang dilakukan oleh Negoro yang mengatakan bahwa siswa/i banyak sekali merasakan manfaat selama menjalankan program tersebut, di antaranya mereka mendapatkan ilmu pengetahuan yang lebih, karena dapat mengulang pembelajaran yang lalu, dapat memotivasi siswa/i untuk melanjutkan pendidikan ke jenjang yang lebih tinggi, dapat meningkatkan silaturrahim dengan warga sekolah baik guru, siswa, pegawai sekolah dan lain sebagainya, ${ }^{5}$ sedangkan pihak yang kontra berpandangan bahwa, kegiatan FDS akan menambah beban guru dan siswa. Guru bukan hanya mengurus murid-muridnya di sekolah, tetapi juga mengurusi suami, anak atau istri. Selain guru, siswa juga berpotensi mengalami kebosanan atau stres karena berada di sekolah sepanjang hari. Apalagi jika program yang direncanakan sekolah kurang menarik dan variatif, termasuk juga waktu belajar anak berkurang di sore hari seperti diniyah dan lain sebagainya.

${ }^{2}$ H. Akmal Hawi, "Sistem Full Day School di Sekolah Dasar Islam Terpadu (SDIT) Studi Kasus di Izzuddin Palembang," Istinbath XIV, no. 16 (2015): 71-87.

3 Az-Zuhri, Dhilla Nuraeni, "Pro dan Kontra Full Day School," NU ONLINE, 11 Agustus 2017.

${ }^{4}$ Jurnalis, "Ini Kelebihan dan Kekurangan Full Day School," OKEZONE News, 09 Agustus 2016.

${ }^{5}$ Negoro, R Ady, "Persepsi Siswa Kelas XI tentang Program Full Day School di SMA Negeri 2 Sawahlunto," Skripsi, 2014. 
Begitu juga dengan pendapat Berthelon yang mengatakan bahwa "In order to analyze the role of instruction time, we compared outcomes according to schools' FDS status; however, only voucher and public schools were required to subscribe to the fullday reform, and children in publicly-funded schools performed slightly worse than the national average. Within publicly funded schools, reveal that on average, SIMCE scores were lower in FDS schools compared half-day school."6

Ternyata tidak berhenti sampai di sini, pembelakuan FDS mendapat kritik dari masyarakat yaitu: pertama, pembelajaran sehari penuh membutuhkan kesiapan fisik dan psikologis. Jika tidak siap, siswa akan bosan bahkan frustasi. Kedua, anak-anak akan banyak kehilangan waktu untuk belajar tentang hidup bersama keluarganya di rumah. Ketiga, penerapan konsep ini di sekolah swasta dan membutuhkan biaya yang umumnya lebih mahal daripada sekolah biasa. ${ }^{7}$

Para pakar pendidikan yang pro menilai FDS sebagai alternatif solusi dari revolusi pendidikan terhadap permasalahan yang terjadi di dunia pendidikan, sedangkan para pakar pendidikan yang kontra menilai, penerapan FDS ini sebagai bentuk kekeliruan menyikapi pendidikan dan persekolahan, seakan-akan pendidikan hanya identik dengan sekolah, padahal makna pendidikan jauh lebih luas. Full day school sendiri adalah istilah dari proses pembelajaran yang dilaksanakan secara penuh, di mana aktifitas belajar anak dilakukan lebih banyak di sekolah daripada di rumah. Proses belajar mengajar diberlakukan di pagi hari sampai dengan sore hari, namun, perlu diketahui bersama bahwa, konsep dasar full day school sama dengan pendidikan Islam, di mana aplikasinya bertujuan agar memanfaatkan waktu dengan melakukan hal yang bermanfaat, ini adalah manifestasi dari belajar tanpa batas. Pendidikan Islam sebagai usaha untuk membimbing pertumbuhan dan perkembangan kepribadian siswa supaya mereka hidup sesuai dengan ajaran Islam.

Konsep awal dibentuknya sistem full day school ini bukan menambah materi ajar dan jam pelajaran yang sudah ditetapkan oleh Kementrian Pendidikan Nasional, seperti yang ada dalam kurikulum tersebut, melainkan tambahan jam sekolah digunakan untuk pengayaan materi ajar yang disampaikan dengan metode pembelajaran yang kreatif dan menyenangkan untuk menambah wawasan dan memperdalam ilmu

\footnotetext{
${ }^{6}$ Matias Berthelon, Diana Kruge, Veronica Vienne, "Longer School Schedules and Early Reading Skills: Effects from a Full-Day School Reform in Chile," IZA DP No. 10282, (2016): 7

${ }^{7}$ Jurnalis, "Ini Kelebihan dan Kekurangan Full Day School."
} 
Hasan Baharun, Saudatul Alawiyah: Pendidikan Full Day School...

pengetahuan, menyelesaikan tugas dengan bimbingan guru, pembinaan mental, jiwa dan moral anak, dengan kata lain konsep dasar dari full day school ini adalah integrated curriculum dan integrated activity. ${ }^{8}$

Full day school ditunjang dengan berbagai alasan yang patut dipertimbangkan dalam pendidikan siswa. Seperti yang dikemukakan oleh Clark sebagaimana dikutip oleh Setiarini; ${ }^{9}$ "The growing number of all-day programs is the result of a number of factors, including the greater numbers of single-parent and dual-income families in the workforce who need all-day programming for their young children, as well as the belief by some that all-day programs better prepare children for school." Hal demikian untuk untuk membentuk moral dan karakter peserta didik, merencanakan sebuah perencanaan program dalam sistem pembelajaran full day school akan berhasil, bila didukung oleh perencanaan pembelajaran yang baik dan sesuai. Perencanaan tersebut dalam bentuk perangkat pembelajaran yang disusun guru berupa prota, promes, silabus, RPP, penilaian, ${ }^{10}$ dan remedial. Pelaksanaan sistem pembelajaran full day school bertujuan untuk mencetak generasi shalih dan berprestasi sesuai dengan visi dan misi sekolah.

Mengingat pentingnya pendidikan dalam upaya mengangkat harkat dan martabat serta menyiapkan manusia yang memiliki intelektualitas, spiritualitas dan al-akhlaq alkarimah, maka pendidikan semacam ini memerlukan suatu usaha dan pemikiran yang keras dan serius dalam upaya mewujudkan cita-citanya. ${ }^{11}$

Dalam epistemologi Islam adalah bagaimana Islam melahirkan ilmu pengetahuan atau teori kebenaran, menyangkut metode, kemungkinan- kemungkinan, asal mula, sifat alami, batas-batas, asumsi landasan serta prosedurnya seperti tingkat validitas dan realibilitas. Epistemologi Islam dalam konteks pendidikan adalah bagaimana Islam membahas isu memanusiakan manusia menjadi manusia menurut pandangan Islam sehingga menelurkan ilmu pendidikan Islam, berkaitan dengan

\footnotetext{
${ }^{8}$ Ida Nurhayati Setiarini, Sutarno Joyoatmojo, Sunardi, "Penerapan Sistem Pembelajaran "Fun dan Full Day School' untuk Meningkatkan Regiliusitas Peserta Didik di SDIT AL ISLAM Kudus," Jurnal Teknologi Pendidikan dan Pembelajaran 2, no. 2 (2014): 238

${ }^{9}$ Ibid

${ }^{10}$ Penilaian bertujuan untuk memantau proses dan kemajuan belajar peserta didik serta meningkatkan efektivitas kegiatan pembelajaran. Lihat: Hasan Baharun, "Penilaian Berbasis Kelas Pada Pembelajaran Pendidikan Agama Islam Di Madrasah," MODELING: Jurnal Program Studi PGMI 3, no. 2 (2016): 205-206.

11 Hasan Baharun, "PENDIDIKAN ANAK DALAM KELUARGA: TELAAH EPISTEMOLOGIS,” Pedagogik 3, no. 2 (2016): 96-107.
} 
pembangunan ilmu yang Islami, belakangan ini muncul upaya Islamisasi ilmu pengetahuan sebagai jawaban terhadap perkembangan pengetahuan yang dianggap jauh dari ajaran dan nilai Islam. ${ }^{12}$

Dalam hal ini, agama memandang konsep full day school dengan kaca mata positif karena konsep full day school sekufu dengan tujuan pendidikan Islam itu sendiri, seperti yang telah dikemukakan pada paragraph sebelumnya, sehingga peneliti tertarik untuk mengkaji pendidikan full day school dalam perspektif epistemologi Islam dalam teori pemikiran Muhammad 'Abid Al- Jabiri.

\section{B. Pendidikan Full Day School}

Konsep full day school syang awalnya merupakan Peraturan Menteri, kini berubah menjadi Peraturan Presiden. Hal ini bertujuan untuk memberi pemahaman terhadap masyarakat terkait kebijakan yang telah ditentukan. ${ }^{13}$

Sedikit mengetahui sejarah munculnya full day school, sistem atau program ini lahir pada awal tahun 1980-an di Amerika Serikat yang awalnya diterapkan untuk sekolah taman kanak-kanak, kemudian akhirnya melebar kejenjang yang lebih tinggi seperti sekolah dasar dan menengah atas. Dan Sistem full day school di Indonesia di awali dengan menjamurnya istilah sekolah unggulan sekitar tahun 1990-an, yang banyak dipelopori oleh sekolah-sekolah swasta termasuk sekolah-sekolah yang berlabel Islam. Dalam pengertian yang ideal sekolah unggul adalah sekolah yang berfokus pada kualitas proses pembelajaran, bukan pada kualitas input siswanya. Kualitas proses pembelajaran bergantung pada sistem pembelajarannya, namun faktanya sekolah unggulan biasanya ditandai dengan biaya yang mahal, fasilitas yang lengkap dan serba mewah, elit, lain daripada yang lain, serta tenaga-tenaga pengajar yang professional, kemudian kata-kata full day school, merupakan kata yang berasal dari bahasa Inggris yang terdiri dari tiga (3) kata, yaitu full-day-school, secara perkata dapat diartikan full yaitu penuh, day yaitu hari dan school yaitu sekolah. Apabila digabungkan maka berarti

\footnotetext{
${ }^{12}$ Buseri Kamrani, "Epistemologi Islam dan Reformasi Wawasan Pendidikan," Jurnal Ilmiah Peuradeun: International Multidisciplinary Journal 3, no. 1 (2015): 78

${ }^{13}$ Ahmad Romadoni, "Perpres Full Day School Masuk Sinkronisasi, (22 Agustus 2017), http://news.liputan6.com/read/3066764/perpres-full-day-school-masuk-tahap-sinkronisasi. Diakses pada 10 Oktober 2017.
} 
Hasan Baharun, Saudatul Alawiyah: Pendidikan Full Day School...

"sekolah sehari penuh," dapat juga diartikan "sistem pembelajaran sepanjang hari" atau "pendidikan di sekolah lebih lama."14

Full-day school juga mempunyai pengertian waktu pembelajaran hingga sore hari. Yang pada intinya konsep full day school ini dalam pengertian yang sebenarnya ditandai oleh waktu belajar yang lebih lama daripada sekolah-sekolah konvensional serta interaksi antara peserta didik dan pengaruh gurunya lebih intensif. Jika dilihat dari dua makna diatas, Full day school memberikan kesempatan lebih banyak kepada siswa siswi untuk memperbaiki hal-hal yang kurang maksimal sehingga menjadikan maksimal sesuai dengan tujuan pendidikan yang telah ditetapkan. Untuk mencapai tujuan tersebut tentunya memerlukan waktu yang panjang dalam prosesnya tanpa perlu mencari les atau kursus tambahan, karena semuanya terpenuhi dan tersedia di sekolah. Full day sebenarnya pendidikan karakter, yaitu pilihan dengan menambah jam belajar di sekolah, kemudian diisi dengan aktivitas-aktivitas bermacam-macam. Full day adalah cara mendongkrak sistem pendidikan yang masih rendah. ${ }^{15}$

Full day school adalah salah satu karya cerdik para pemikir dan praktisi pendidikan untuk mensiasati minimnya kontrol orang tua terhadap anak di luar jam-jam sekolah formal sehingga sekolah yang awalnya dilaksanakan 5 sampai 6 jam berubah menjadi 8 bahkan sampai 9 jam, namun demikian, problema-problema pendidikan bukan berarti selesai sampai di situ, melainkan timbul problem-problem baru yang perlu dikaji secara serius sehingga pendidikan dapat memproses bibit-bibit generasi (input) menjadi pribadi-pribadi (output) yang mempunyai kematangan mental, intelektual dan skill yang mumpuni. Menurut Sismanto, full day school merupakan model sekolah umum yang memadukan sistem pengajaran Islam secara intensif yaitu dengan memberi tambahan waktu khusus untuk pendalaman keagamaan siswa. ${ }^{16}$

Menurut Sujianto, sebagaimana dikutip oleh Siregar, beberapa hal yang melatar belakangi munculnya tuntutan full day school antara lain: pertama, minimnya waktu orang tua di rumah berinteraksi dengan anak dikarenakan kesibukan dari tuntutan pekerjaan. Kedua, meningkatnya single parents dan banyaknya aktifitas orang tua yang kurang memberikan perhatian pengawasan dan keamanan, serta kenyamanan terhadap

\footnotetext{
${ }^{14}$ Jhon Echlos, Kamus Inggris Indonesia (Jakarta: Gramedia,1996), 260

${ }^{15}$ Muhadjir Efendy, "Full Day School," http://news.detik.com(19 Agustus 2016), diakses pada 10 Oktober 2017.

${ }^{16}$ Lis Yulianti Syafrida Siregar, "Full Day School sebagai Penguatan Pendidikan Karakter," Fikrotuna: Jurnal Pendidikan dan Manajemen Islam 5, no. 2 (2017): 311
} 
segala tuntutan kebutuhan anak, terutama bagi anak usia dini. Ketiga, perlunya formulasi jam tambahan keagamaan bagi anak dikarenakan minimnya waktu orang tua bersama anak. Keempat, peningkatan kualitas pendidikan sebagai sebuah alternatif solusi terhadap berbagai permasalahan kemerosotan bangsa, terutama akhlak. Kelima, semakin canggihnya dunia komunikasi, membuat dunia seolah-olah tanpa batas (borderless world) yang dapat mempengaruhi perilaku anak jika tidak mendapat pengawasan dari orang dewasa. ${ }^{17}$

Penerapan full day school dalam rangka memaksimalkan waktu luang anak-anak agar lebih berguna. Sistem full day school dengan belajar sehari penuh bukanlah sistem baru dalam pendidikan Islam. Di Indonesia konsep pendidikan ini sudah ada sejak lama, yaitu di pondok pesantren. Umumnya siswa belajar sehari penuh bahkan sampai larut malam untuk mempelajari agama Islam (al-Qur'an dan al-Hadits) dan pengetahuan umum lainnya, pendidikan ini terpola pada pendidikan pesantren yang menerapkan boarding school (sekolah berasrama).

Sistem full day school mempunyai sisi keunggulan, antara lain:

1. Sistem full day school lebih memungkinkan terwujudnya pendidikan secara utuh, maksudnya adalah sasaran dan tujuan obyektifitas pendidikan meliputi tiga ranah yaitu: kognitif, afektif dan psikomotor, sebab melalui system school tendensi yang mengarah pada penguatan sisi kognitif saja bisa dihindarkan dan sisi afektif dan psikomotor bisa lebih terarahkan.

2. Sistem full day school lebih memungkinkan terwujudnya intensifikasi dan efektivitas proses edukasi. Full day school sengan menggunakan waktu lebih panjang sangat memungkinkan bagi terwujudnya intensifitas proses pendidikan dalam arti siswa/i lebih mudah diarahkan dan dibentuk sesuai dengan misi dan orientasi pendidikan, sebab aktifitas siswa/i lebih mudah dikontrol.

3. System full day school merupakan sistem pendidikan yang terbukti efektif dalam mengaplikasikan kemampuan siswa/i dalam segala hal, seperti aplikasi Pendidikan Agama Islam (PAI) yang mencakup semua aspek baik ranah kognitif, afektif dan psikomor. ${ }^{18}$

\footnotetext{
${ }^{17}$ Ibid., 308

${ }^{18}$ Nor Hasan, "Full Day School Model Alternative Pembelajaran PAI," Jurnal Pendidikan
} Tadris 1, no. 1 (2006): 114-115 
Hasan Baharun, Saudatul Alawiyah: Pendidikan Full Day School...

Namun demikian, sistem pembelajaran full day school ini tidak terlepas dari kelemahan atau kekurangan, antara lain:

1. Sistem full day school seringkali menimbulkan rasa bosan pada siswa/i. sistem pembelajaran tersebut membutuhkan kesiapan fisik, psikologis dan intelektual yang bagus serta diperlukan kejelian dan improvisasi pengelolaan sehingga tidak monoton dan membosankan.

2. Sistem full day school memerlukan perhatian dan kesungguhan manajemen bagi lembaga pengelola agar, proses pembelajaran berlangsung optimal serta, dibutuhkan sarana dan prasarana pendukung yang bersifat material.

3. Dibutuhkan Tenaga pengajar professional dan kompeten di bidangnya. ${ }^{19}$

\section{Epistemologi Islam}

Pada kenyataan yang terjadi pada saat ini bahwa sepanjang sejarah pemikiran manusia telah terjadi perdebatan panjang para filosof mengenai poin-poin pembahasan epistemologi. Perdebatan tersebut telah menghasilkan berbagai aliran filsafat dan ideologi yang memiliki pandangan yang berbeda terhadap permasalahan mengenai pengetahuan dan kehidupan manusia, maka dari itu sebelum masuk pada pembahasan inti, perlunya melihat dan meninjau berbagai pendapat para pakar tentang pengertian epistemologi dan Islam.

Epistemology, (which comes from the Greek word episteme) inquires into the nature of knowledge and justification of belief. Indeed, many writers prefer to use the label "The theory of knowledge," "Epistemology, however has an advantage of being a philosophical term of art, whereas the theory of knowledge could also apply to the investigators of sociologists of knowledge and historians of ideas. ",20

Menurut pakar pendidikan, epistemologi berasal dari kata "episteme" yang berarti pengetahuan. Epistemologi adalah ilmu yang membahas tentang "apa pengetahuan dan bagaimana memperoleh pengetahuan."21 Menurut pendapat lain, epitemologi berarti ilmu filsafat tentang pengetahuan, atau dengan pendek kata, filsafat

${ }^{19}$ Idusardi, "Sekolah Kehidupan Berbasis Realita (Kritik atas Gagasan Full day school 19 Agustus 2016), diakses pada 10 Oktober 2017, http://re-searchingines.com

${ }^{20}$ M. Azram, "Epistemology an Islamic Perspective," IIUM Engineering Journal 12, no. 5 (2011): 179

${ }^{21}$ Muzayyin Arifin, Filsafat pendidikan Islam (Jakarta: Bumi Aksara,2003), 7 
pengetahuan, epistemology is defined as the theory of knowledge, ${ }^{22}$ yaitu berkaitan dengan masalah-masalah yang meliputi:

1. Filsafat yaitu sebagai ilmu berusaha mencari hakekat dan kebenaran pengetahuan.

2. Metode yaitu sebagai metode bertujuan mengantarkan manusia untuk memperoleh pengetahuan.

3. Sistem yaitu sebagai suatu sistem bertujuan memperoleh realitas kebenaran pengetahuan. $^{23}$

Epistimologi adalah salah satu cabang filsafat yang membahas tentang hakikat pengetahuan manusia. Persoalan pokok yang berkembang dalam epistemologi adalah meliputi sumber-sumber pengetahuan, watak dari pengetahuan manusia, apakah pengetahuan itu benar (valid) ataukah tidak, bagaimana pengetahuan manusia itu didapat, dengan cara apa dan apa saja syarat-syarat yang harus dipenuhi, sehingga epistemologi sampai pada problem hubungan metodologi dengan obyek dari ilmu pengetahuan. ${ }^{24}$ Dalam sejarah filsafat Barat epistemologi telah menghasilkan empat aliran utama yaitu:

1. Rasionalisme sebagai paham yang sangat menekankan akal sebagai sumber utama pengetahuan manusia dan pemegang otoritas terakhir dalam penentuan kebenaran pengetahuan manusia.

2. Empirisme sebagai paham yang sangat menekankan pengalaman sebagai sumber utama pengetahuan manusia.

3. Intuitisme sebagai paham yang sangat menenkankan bisikan hati sebagai sumber utama pengetahuan manusia. ${ }^{25}$

Sedangkan Islam sendiri, dari segi bahasa berasal dari bahasa Arab, yaitu dari kata salima yang mengandung arti selamat, sentosa dan damai. Dari kata salima selanjutnya dirubah kekata aslama yaitu berserah diri masuk dalam kedamaian. ${ }^{26}$ Dan

${ }^{22}$ Fadzila Azni Ahmad, "Philosophical Underpinnings of Islamic Management Method: Worldview, Epistemology and Ontology," International Journal of Humanities and Social Science 2, no. 20 [Special Issue] (2012): 153

${ }^{23}$ Nasrah, "Pengetahuan Manusia dan Epistemologi Islam," e-USU-Jurnal Repository 4, no. 2 (2008): 4

24 Anwar Mujahidin, "Epistemologi Islam: Wahyu sebagai Sumber Ilmu,"Ulumuna Jurnal Studi Keislaman 17, no. 1 (2013): 42

25 A. Khudori Soleh, "Model-model Epistemologi Islam," Nitro PDF Professional, (2010): 194

\footnotetext{
${ }^{26}$ Abuddin Nata, Metodologi Study Islam (Jakarta: PT. RajaGrafindo Persada, 2000), 95
} 
Hasan Baharun, Saudatul Alawiyah: Pendidikan Full Day School...

Islam sebagai agama akhir zaman merupakan agama yang terlibat langsung dalam pergumulan IPTEK dan era informasi telah jauh hari mempersiapkan umatnya untuk memiliki ilmu. ${ }^{27}$ Isyarat-isyarat untuk mencari ilmu dapat dijumpai seperti surat yang pertama kali diturunkan Allah. Adapun menurut istilah Islam ialah agama yang ajarannya diwahyukan tuhan kepada masyarakat melalui nabi Muhammad SAW sebagai Rasul. ${ }^{28}$ Islam pada hakikanya membawa ajaran yang tidak memandang satu sisi saja namun, pada semua sisi dari kehidupan manusia, jadi epistemologi Islam adalah bagaimana Islam menghasilkan ilmu pengetahuan atau teori kebenaran, menyangkut metode, kemungkinan- kemungkinan, asal mula, sifat alami, batas-batas, asumsi dan landasan serta bagaimana prosedurnya seperti tingkat validitas dan realibilitas. Epistemologi Islam dalam konteks pendidikan adalah bagaimana Islam membahas isu memanusiakan manusia menjadi manusia menurut pandangan Islam sehingga menghasilkan ilmu pendidikan Islam. Berkaitan dengan pembangunan ilmu yang Islami, belakangan muncul upaya Islamisasi ilmu pengetahuan sebagai jawaban terhadap perkembangan pengetahuan yang dianggap jauh dari ajaran dan nilai Islam. ${ }^{29}$ Epistemologi Islam juga sebagai dasar reformasi wawasan pendidikan melalui penelaahan secara mendalam, komprehensif, sistematis dan terarah terhadap objeknya yakni bagaimana memanusiakan manusia dengan segenap problematika yang sedang dihadapinya saat ini, disebabkan isu-isu pendidikan terus berubah dan berkembang, maka reformasi adalah menjadi keharusan. ${ }^{30}$ Menurut Dacholfany bahwa orientasi pendidikan Islam di Indonesia masih mengalami perbedaan pendapat, terutama dalam menentukan pola, arah, dan capaian tertentu yang diinginkan, sehingga pendidikan Islam belum mendapat pengakuan secara internasional dalam era global ini maka seyogyanya orientasi pendidikan Islam bukan hanya dengan model-model pendidikan dan pembelajaran seperti yang sudah ada sekarang ini, yang seharusnya terus menerus melakukan reformasi (pembaruan) dan inovasi serta kerja keras untuk memperbaiki kelemahan dan kekurangan menuju langkah baru ke arah kemajuan dan perkembangan

\footnotetext{
${ }^{27}$ Nasrah, "Pengetahuan Manusia dan Epistemologi Islam," 1

${ }^{28}$ Harun Nasution, Filsafat Islam (Jakarta: Bulan Bintang, 1978), 10

${ }^{29}$ Kamrani Buseri, "Epistemologi Islam," 78

${ }^{30}$ Ibid.
} 
sesuai dengan tuntutan zaman sehingga pemerataan, mutu, relevansi, dan efektif dan efisiensi dari pendidikan dapat diselesaikan dengan baik dan benar. ${ }^{31}$

Dalam kajian pemikiran Islam terdapat juga beberapa aliran besar dalam kaitannya dengan epistemologi, setidaknya ada tiga model sistem berfikir dalam Islam, yaitu:

1. Epistemologi bayani adalah metode pemikiran khas Arab yang didasarkan atas otoritas teks (nash) secara langsung atau tidak langsung, secara langsung artinya memahami teks sebagai pengetahuan jadi dan langsung mengaplikasikan tanpa perlu pemikiran, sedangkan secara tidak langsung berarti memahami teks sebagai pengetahuan mentah sehingga perlu tafsir dan penalaran. Meski demikian, hal ini bukan berarti akal dan rasio bisa bebas menentukan makna dan maksudnya, tetapi tetap harus bersandar pada teks, dengan demikian, sumber pengetahuan bayani adalah teks yakni al-Qur'an dan al-Hadits.

2. Epistemologi 'irfani ini tidak didasarkan atas teks seperti bayani tetapi pada kasyf, yaitu tersingkapnya rahasia-rahasia realitas oleh Tuhan, oleh karena itu pengetahuan 'irfani tidak diperoleh berdasarkan analisa teks tetapi dengan olah ruhani. Di mana dengan kesucian hati, diharapkan tuhan akan melimpahkan pengetahuan langsung kepadanya, masuk dalam pikiran dan dikonsep kemudian dikemukakan kepada orang lain secara logis. Dengan demikian, pengetahuan 'irfani setidaknya diperoleh melalui tiga tahapan: persiapan, penerimaan dan pengungkapan baik melalui lisan maupun tulisan. Pengetahuan ini juga bisa disebut dengan pengetahuan intuisi yaitu pengetahuan yang berkaitan dengan alam kejiwaan. ${ }^{32}$

3. Epistemologi burhani ini berbeda dengan bayani dan 'irfani yang masih berkaitan dengan teks suci, burhani sama sekali tidak mendasarkan diri pada teks, tetapi burhani mendasarkan diri pada kekuatan rasio, akan yang dilakukan lewat dalil-dalil logika, jadi perbandingan untuk ketiga epistemologi Islam ini yaitu, bayani menghasilkan pengetahuan lewat analogi furu' kepada yang asal, 'irfani menghasilkan pengetahuan lewat proses penyatuan ruhani pada tuhan,

${ }^{31}$ M. Ihsan Dacholfany, "Reformasi Pendidikan Islam dalam Menghadapi Era Globalisasi: Sebuah Tantangan dan Harapan," Jurnal Akademika 20, no. 01 (2015): 179.

${ }^{32}$ Ali Abdul Azhim, Epistemologi dan Aksiologi Ilmu Perspektif Al-Qur'an (Bandung: CV. Rosda, 1989), 16 
dan burhani menghasilakan pengetahuan melalui prinsip-prinsip logika atas pengetahuan sebelumnya yang telah diyakini kebenarannya. ${ }^{33}$

Dalam hal ini, epistemologi Islam dalam sejarahnya, terbukti mampu mengantarkan zaman klasik Islam menuju pada kemampuan membangun ilmu dan kebudayaan yang tidak dikotomik. Pengembangan sains yang berakar pada epistemologi dan sistem nilai Islam menjadi sebuah sains yang dapat diinternalisasikan dan bisa mengekspresikan tanggung jawab sosial kaum Muslim. ${ }^{34}$ Epistemologi Islam dibangun di atas berbagai pendekatan, mulai pendekatan tekstual yang menjadikan teks-teks kitab suci dan hadis sebagai titik tolak pertama dan penentu kebenaran (bayani), kemudian diperkaya dengan pendekatan kalam dan filsafat yang bersifat spekulatif-rasional (burhani), dan pada akhirnya diperhalus dengan pendekatan mistis ('irfani). Kesemua pendekatan tersebut pada dasarnya dapat digunakan secara bersamaan (jama 'i), kendati mungkin karena alasan objek yang beragam terkadang satu pendekatan lebih dominan dibanding yang lain. Akan tetapi, yang jelas, berbagai pendekatan itu pada kurun sejarah Islam yang sangat panjang telah memengaruhi para ilmuan dalam memahami berbagai entitas keilmuan dalam Islam.

\section{Full Day School dalam Perspektif Epistemologi Islam}

Membahas full day school tak lepas dari tujuan pendidikan Islam itu sendiri, sebab FDS dirangkai untuk memadukan pengetahuan umum dan agama. Di samping itu, sebab pula munculnya model dan program FDS ini merupakan salah satu solusi dari berbagai problematika pendidikan yang ada. Maka dari itu, sebelum membahas pada inti permasalahan, dapat diketahui dari apa tujuan pendidikan Islam itu sendiri?

Pendidikan Islam menurut Ahmad D. Marimba adalah bimbingan jasmani dan rohani berdasarkan hukum-hukum agama Islam menuju kepada terbentuknya kepribadian yang utama menurut ukuran-ukuran ajaran Islam.

Dalam hal ini, sebagai agen of change, pendidikan Islam yang berada dalam atmosfir globalisasi sekarang ini diharapkan dapat memainkan perannya secara dinamis dan proaktif. Eksistensinya ilmuwan Islam sebagai pembaharu diharapkan bisa melakukan perubahan dan memberikan kontribusi yang bermakna bagi perubahan dan

${ }^{33}$ A. Khudori Soleh, "Model-model Epistemologi Islam,” 194-197

34 Musliadi, "Epistemologi Keilmuan dan Islam (Kajian terhadap Pemikiran M. Amin Abdullah)," Jurnal Ilmiah Islam Futura 13, no.2 (2014): 179 
perbaikan umat Islam, baik pada tataran intelektual teoritis maupun praktis dengan cara mempertahan dan menjaga hal-hal yang masih baik dan membuat atau mengambil hal baru yang baik. Sebagaimana ungkapan bijak: "Al-muhafazhah 'ala al-qadimi al-shalih wa al-akhdzu bi al-jadidi al-ashlah. ${ }^{35}$

Dari tujuan di atas memang seharusnya tidak melupakan kodrat manusia yang diciptakan sebagai 'abdullah dan khalifatullah yang memiliki fitrah atau potensi, di mana fitrah sendiri memerlukan aktualisasi atau pengembangan lebih lanjut sebab tanpa aktualisasi fitrah tersebut akan ditutupi oleh polusi yang dapat membuat manusia berpaling dari kebenaran, ${ }^{36}$ selain itu, adanya program-program dan model-model dalam pendidikan tentu harus bertanya dulu kepada al-Qur`an dan as-Sunnah terkait dengan gambaran, gagasan, pandangan, norma, nilai, petunjuk serta motivasi apa yang disyaratkan oleh Tuhan, agar hasil yang diperoleh sesuai dengan tujuan yang diharapkan, lalu bagaimana Islamization of knowledge memandang full day school?

Sejak diterapkannya FDS di Indonesia dan diresmikan oleh KEMENDIKBUD pada tgl 12 Juni 2017 dengan menetapkan Peraturan Menteri yang tercatat dalam pasal No 23 tahun 2017 memunculkan respon pro dan kontra antar masyarakat. Mengapa demikian? Karena mereka hanya bermain dengan pikiran mereka masing-masing. Pada hakikatnya FDS bisa dimanfaatkan dengan baik apabila mengikuti kaidah-kaidah evidence-based training approach. Dan dalam hal ini juga dibutuhkan perencanaan yang sangat matang.

Jika dikutip dari beberapa wacana tentang pendidikan Islam, program FDS dan konsep yang dirangkainya merupakan bentuk dukungan terhadap tercapainya tujuan pendidikan Islam. Seperti yang dikatakan salah satu pakar pendidikan yaitu Menurut Muhammad Qutb, di dunia muslim, agama berangsur- angsur lenyap dari pemikiran dan hati mereka. Rumah dan lingkungan berkontradiksi, semakin memperparah keadaan dan kurikulum sekolah tidak mencukupi. Pendidikan formal di sekolah atau pendidikan melalui khutbah- khutbah, penerangan agama melalui radio dan televisi jauh dari keberadaan agama dan sering kali irreligious.

\footnotetext{
${ }^{35}$ M. Ihsan Dacholfany, "Reformasi Pendidikan Islam dalam Menghadapi Era Globalisasi: Sebuah Tantangan dan Harapan, Jurnal Akademika 20, no. 01 (2015): 190.

35 Ali Abdul Azhim, Epistemologi dan Aksiologi Ilmu Perspektif Al-Qur'an (Bandung: CV. Rosda, 1989), 68 2011), 46
} 
Diketahui bahwa materi yang diajarkan dan metode yang digunakan sama sekali tidak berbeda dari apa yang ada di Barat yakni dunia yang mutlak anti agama walaupun keadaan itu disembunyikan di belakang layar sekularisme. Terpisahnya penilaian (evaluasi) antara pengetahuan dan penghayatan keagamaan dalam evaluasi hasil belajar, mengurangi makna pendidikan itu sendiri, sebab pendidikan agama dikatakan berhasil bilamana nilai telah menyatu dalam pribadi anak di saat berkomunikasi dengan dunianya, ${ }^{37}$ maka dari itu, konsep FDS sangat baik diterapkan hanya saja perlu memperhatikan objek yang dituju artinya harus lebih proposional lagi dalam menetapkan kebijakan, karena unsur dasar pendidikan utamanya meliputi: yang memberi, yang menerima, tujuan yang baik, cara atau jalan yang baik dan konteks yang positif.

Tentu saja karena berpikir epistemologis Islam, maka jawaban yang ada akan lebih kepada jawaban yang bersifat umum atau filosofis. Pembenahan aspek filosofis harus dimulai terlebih dahulu, karena secara hirarki ilmu yang paling dasar adalah filsafat, baru teori dan teorilah yang akan menuntun operasional pendidikan. Untuk mengetahui FDS dari sudut pandang epistemologi Islam, marilah terlebih dahulu menelaah dari segi tata pikir Epistemologi Islam yang terdiri dari bayani, 'irfani, dan burhani.

Pertama, jika dilihat dari sudut pandang epistemologi bayani yang menekankan pada kekuatan teks suci, bahwa di kalangan ulama terdapat kesepakatan bahwa sumber ajaran Islam yang utama adalah al-Qur`an dan al-Sunnah, sedangkan penalaran atau akal pikiran adalah alat untuk memahami al-Qur`an dan al-Sunnah. Ketentuan ini sesuai dengan agama Islam itu sendiri sebagai wahyu yang berasal dari Allah SWT, yang penjabarannya dilakukan oleh Nabi Muhammad SAW. Di dalam al-Qur`an surat alNisa : 59. Adapun dasar pendidikan Islam sudah jelas bersumber dari firman Allah SWT. dan Sunnah Rasulullah SAW. yaitu al-Qur`an dan Hadis. Melaksanakan pendidikan adalah merupakan perintah agama dan perintah Allah SWT. serta merupakan bentuk ibadah kepadaNya. ${ }^{38}$ Dalam al-Qur`an banyak ayat yang menunjukkan perintah tersebut, antara lain dalam surat al-Isra`ayat 72 yang berbunyi:

${ }^{37}$ Kamrani Buseri, "Epistemologi Islam,” 83

38 Enok Ratnaningsih, "Efektivitas Metode Drill dan Resitasi dalam Meningkatkan Pemahaman dan Keterampilan Siswa terhadap Hukum Bacaan Qolqolah dan Ro' di SMP Negeri 1 Subang," Jurnal Pendidikan Agama Islam - Ta'lim 10, no.1 (2012): 79-94 


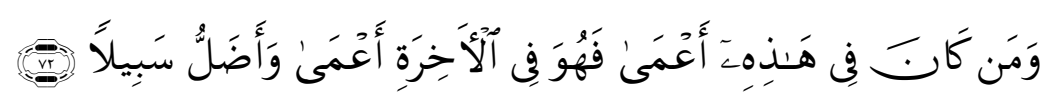

Dan barangsiapa yang buta (hatinya) di dunia ini, niscaya di akhirat (nanti) ia akan lebih buta (pula) dan lebih tersesat dari jalan (yang benar).

Dalam kaitannya dengan FDS, ayat tersebut menyinggung tentang hati yang mati, di mana hati tersebut tidak akan mampu menerima dan menyerap ilmu pengetahuan yang didapatkan ketika di sekolah sebab tidak ada perpaduan antara intelektual dengan spiritual. Dengan begitu, Kemendikbud menyusun konsep FDS disesuaikan dengan kebutuhan perkembangan zaman berdasarkan ayat al-Qur`an.

Dalam surat al-Rahman ayat 1-4 yang berbunyi:

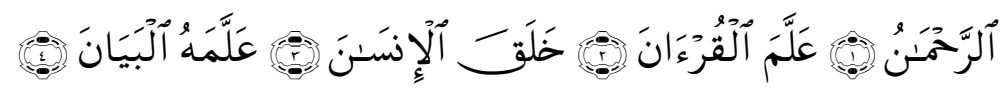

(Tuhan) yang Maha pemurah, Yang Telah mengajarkan Al Quran, Dia menciptakan manusia, Mengajarnya pandai berbicara.

Dalam kaitannya dengan FDS, bahwa ayat di atas mempunyai kesinambungan dengan Peraturan Menteri No. 23 tahun 2017 pasal 1 ayat 3 yang berhubungan dengan prinsip mengajar, jadi penjelasan ayat di atas dimulai dengan kata "Al-Rahman" yang menggambarkan sebuah kasih sayang yang berarti bahwa mengajar itu mempunyai prinsip kasih sayang yang akan melahirkan prinsip-prinsip mengajar lainnya, seperti ikhlas, demokrasi, dan kelembutan terhadap peserta didik. Sehingga akan melahirkan serta memberikan pencerahan intelektual, akidah, dan moral kepada peserta didik.

Dalam al-Qur`an surat al-Jumu'ah (62) ayat 2 yang berbunyi:

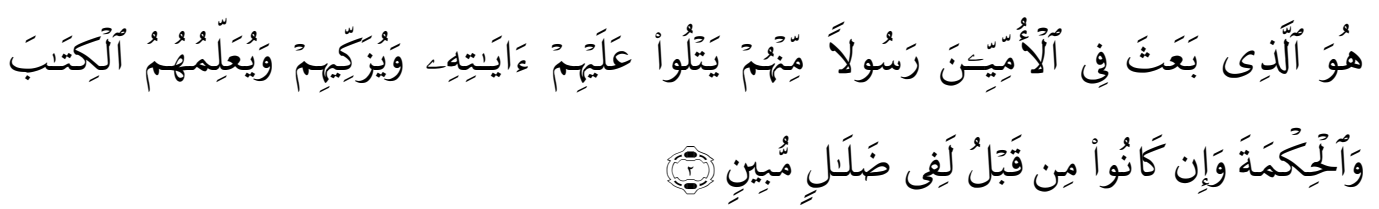

Dia-lah yang mengutus kepada kaum yang buta huruf seorang Rasul di antara mereka, yang membacakan ayat-ayat-Nya kepada mereka, mensucikan mereka dan mengajarkan mereka Kitab dan hikmah (al-Sunnah), dan sesungguhnya mereka sebelumnya benar-benar dalam kesesatan yang nyata.

Ayat di atas sangat berkaitan dengan diterbitkannya kebijakan FDS, bahwa di samping peserta didik mendapatkan berbagai materi tambahan di sekolah, mereka juga mendapatkan pesan-pesan normatif yang meliputi keimanan dan akhlak, sehingga tidak 
Hasan Baharun, Saudatul Alawiyah: Pendidikan Full Day School...

hanya menanamkan ilmu pengetahuan, akan tetapi juga membangun moral dan membersihkannya serta menjauhkannya dari perbuatan-perbuatan tercela.

Dalam surat al-Tahrim ayat 6 yang berbunyi:
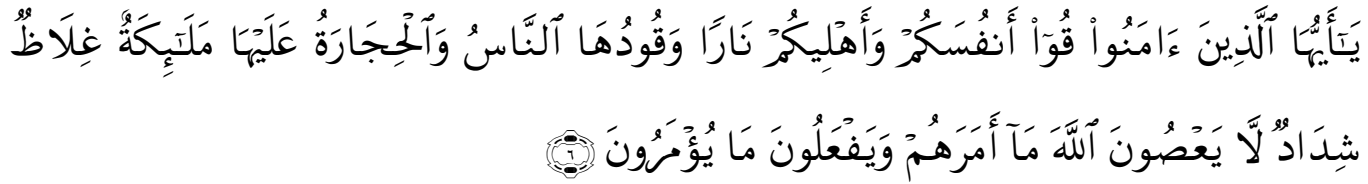

Hai orang-orang yang beriman, peliharalah dirimu dan keluargamu dari api neraka yang bahan bakarnya adalah manusia dan batu; penjaganya malaikatmalaikat yang kasar, keras, dan tidak mendurhakai Allah terhadap apa yang diperintahkan-Nya kepada mereka dan selalu mengerjakan apa yang diperintahkan.

Sangat jelas dari keterangan ayat di atas bahwa sebagai orang tua wajib untuk menjaga anak-anak bahkan seluruh keluarga dari segala yang menjerumuskan ke dalam perbuatan yang dimurkai oleh Allah. Terutama untuk seorang ayah yang tanggung jawabnya sebagai pemimpin kepala rumah tangga sekaligus imam bagi istri dan anakanaknya. Salah satunya dalam memilih pendidikan yang baik untuk anak-anak. Mayoritas pendidikan yang menerapkan kebijakan FDS adalah sekolah unggul yang memiliki fasilitas lengkap sebagai penunjang program yang tengah diterapkan. Jadi, FDS merupakan salah satu alternatif solusi dari berbagai kegelisahan orang tua terhadap pergaulan anaknya.

Tidak terlupakan pula bahwa diterbitkannya kebijakan FDS tentu memiliki tujuan dan harapan yang ingin dicapai, sebagaimana tujuan dalam pendidikan islam itu sendiri, karena tujuan FDS dan pendidikan Islam bagaikan mata uang logam yang tidak memiliki perbedaan sedikitpun, yaitu membentuk peserta didik menjadi insan yang shaleh dan bertakwa kepada Allah SWT. ${ }^{39}$ Sebagaimana firman Allah dalam Q.S. Ali 'Imran (3) ayat 137-138 yang berbunyi:

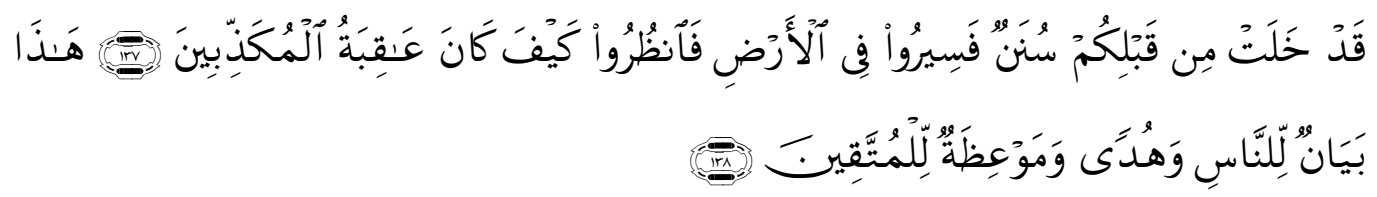

${ }^{39}$ Kadar M.Yusuf, Tafsir Tarbawi (Pesan-pesan al-Qur`an tentang Penddikan) (Jakarta: AMZAH, 2013), 82 
Sesungguhnya telah berlalu sebelum kamu sunnah-sunnah Allah[230]; Karena itu berjalanlah kamu di muka bumi dan perhatikanlah bagaimana akibat orangorang yang mendustakan (rasul-rasul).

Dalam surat An-Nahl ayat 125 yang berbunyi:

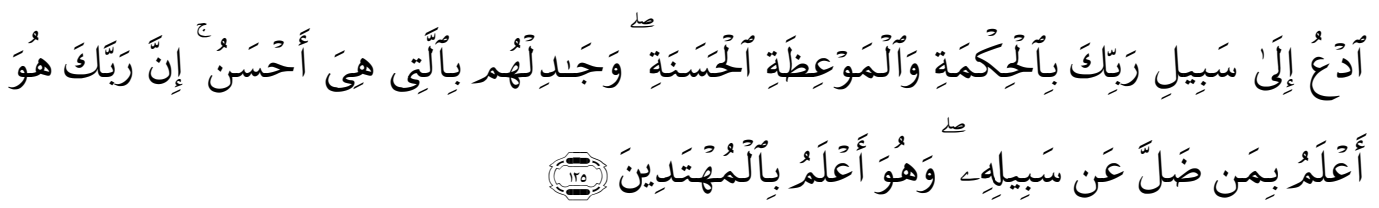

Serulah (manusia) kepada jalan Tuhan-mu dengan hikmah dan pelajaran yang baik dan bantahlah mereka dengan cara yang baik. Sesungguhnya Tuhanmu dialah yang lebih mengetahui tentang siapa yang tersesat dari jalan-Nya dan Dialah yang lebih mengetahui orang-orang yang mendapat petunjuk.

Ayat-ayat al-Qur`an di atas merupakan seruan dari Allah kepada manusia baik laki-laki maupun perempuan agar tidak menyia-nyiakan waktu dengan melakukan halhal yang tidak bermanfaat. ${ }^{40}$ Full day school merupakan manifestasi belajar tanpa batas. Mengacu pada ayat-ayat tersebut di atas bahwa sistem full day school siswa dapat ikut serta pada aktifitas-aktifitas belajar yang menguntungkan selama sehari penuh, sehingga siswa tidak ada waktu luang untuk melakukan aktifitas-aktifitas yang sifatnya negatif dan kurang bermanfaat.

Kedua, jika dilihat dari sudut pandang epistemologi 'irfani, maka tolok ukur dari pengetahuan ini adalah siswa/i memiliki kecerdasan spiritual, karena menurut paham 'irfani ini pengetahuan tidak hanya didapatkan melalui empiris atau pengalaman indriawi serta penalaran rasional semata, akan tetapi juga bisa didapatkan melalui ilham. Menurut Imam al-Ghazali, ilham yaitu jalan pengetahuan yang benar, ia dapat mengantarkan manusia kepada 'ilm al-yaqin yaitu suatu keadaan yang benar-benar terbuka padanya sesuatu yang diketahui sehingga tidak ada lagi mengandung keraguan, ${ }^{41}$ dengan demikian untuk mendapatkan ilmu pengetahuan melalui ilham maka harus menempuh jalan kehidupan dengan mujahadah dan riyadhah. Artinya dalam hal ini jika dikaitkan dengan kebijakan FDS yang telah diterbitkan oleh Perpres, maka harus mendekatkan diri kepada Allah, karena dengan begitu siswa/i akan mudah mendapatkan pengetahuan yang berasal dari Allah melalui kebiasaan-kebiasaan keagamaan yang terkonsep dalam kebijakan FDS. Seperti do'a, sholat dan kegiatan

\footnotetext{
${ }^{40}$ Lis Yulianti Siregar, "Full Day School," 315

${ }^{41}$ Kadar M.Yusuf, Tafsir Tarbawi, 28
} 
Hasan Baharun, Saudatul Alawiyah: Pendidikan Full Day School...

keagamaan yang lainnya, sebab tujuan adanya kebijakan FDS ini semata-mata hanya ingin membekali siswa/i denagn ilmu agama dan menyatukannya dengan ilmu umum, yaitu menumbuhkan keimanan dan ketaqwaan kepada Allah, sehingga, di samping siswa/i memperoleh ilmu pengetahuan melalui garakan-gerakan batin sebagai bentuk ikhtiar dalam menyucikan dirinya dari dosa dan noda, kebiasaan ini merupakan pula bentuk pengalaman puncak yang tidak bisa dikomunikasikan, memang secara logika ilmu pengetahuan ini dianggap sebagai ilmu yang abstrak akan wujudnya, tetapi hal ini hanya bisa dikomunikasikan dengan orang-orang yang memiliki kecerdasan spiritual yang tinggi, mengapa harus cerdas dalam spiritual?, karena orang yang cerdas dalam spiritualnya akan melengkapi kecerdasannya secara intelektual dan emosional, dengan cahaya spiritual juga akan membantu para siswa/i dalam memahami objek pengetahuan yang mudah maupun yang sulit. ${ }^{42}$

Ketiga, dapat dilihat dari sudut pandang epistemologi burhani maka harus memperhatikan kekuatan akal, rasio dan prinsip-prinsip logika, bahwa dalam prinsip logika, seharusnya definisi FDS dirumuskan secara positif, bukan negatif. ${ }^{43}$ Semisal dalam kebijakan yang ditetapkan ialah "Lima hari sekolah dan delapan jam sehari" pertanyaannya, apakah kebijakan tersebut memberikan arti positif untuk membantu menguatkan karakter siswa/i? lalu pertanyaan selanjutnya apa itu karakter dan bagaimana maksud dari penguatan karakter itu sendiri?, mengapa yang diperhatikan hanyalah jam pelajarannya saja?, semisal dengan kondisi sekolah yang minim kuantitas dan kualitas guru dan fasilitas, bahkan berpotensi tidak aman, tepatkah menuntut para siswa menghabiskan waktu begitu lama di sekolah?, akankah watak mereka berubah menjadi lebih mulia karenanya?.

Di sini perlu diketahui bersama bahwa dalam Filosofi Charlotte Mason, untuk mewujudkan watak yang luhur ada tiga pilar yang harus ditegakkan, yaitu:

1. Atmosfer yaitu nilai-nilai yang dipancarkan lewat teladan sehari-hari. Seperti peningkatan kualitas kepribadian dan intelektual para guru.

2. Disiplin yaitu dilatihkannya kebiasaan-kebiasaan baik secara konsisten dan bertujuan. Seperti metode belajar mengajar harus direvolusi.

\footnotetext{
${ }^{42}$ Kalimi, Logika (Teori dan Aplikasi) (Jakarta: Gunung Persada GP Press, 2011), 202

${ }^{43}$ Ellen Kristi, "Bisakah Full day School Menguatkan Karakter?," NU Jateng, 19 July 2017.
} 
3. Dipasok dengan ide-ide positif dan inspiratif, seperti perpustakaan perlu dipasok dengan buku-buku bermutu. ${ }^{44}$

Untuk menambah jam belajar di sekolah hanyalah teknik saja, bukan esensi dari pendidikan karakter, tanpa adanya tiga pilar diatas, watak siswa tetap tak terjamin akan menjadi lebih baik, menjadi pertanyaannya saat ini mengapa paham ini menekankan pada akal atau rasio?, karena akal merupakan hidayah agama Islam dari Allah untuk memikul beban yang diberikan kepada ummatnya. ${ }^{45}$ Maka menggunakan kaca mata ini, FDS sangatlah bagus untuk diterapkan, agar akal seseorang yang sering dikenal dengan "otak" tidak mudah tertidur dan hanya terdiam karena adanya waktu luang tanpa kegiatan yang bermanfaat.

\section{E. Kesimpulan}

Full day school yang dianggap sebagai suatu hal yang baru, ternyata sudah sangat lumrah dikenal dan diketahui. Bahkan, berbagai pendapat dari berbagai kalangan mengalami perbedaan dalam persepsi, sebagian memberikan persepsi positif terhadap FDS, sebagian pula memberikan persepsi negatif, padahal, jika menyadari akan hakikat suatu hal tentu memiliki sisi negatif dan positif, begitu juga dengan FDS. Selanjutnya, dalam dalam pendidikan sudah sepantasnya menyakini hal-hal dengan positif, seperti dalam paham epistemologi bayani yang mengenal sesuatu berdasarkan al-Qur`an dan al-Hadits, sehingga seburuk apapun keadaan yang dihadapi jika mau berfikir positif, maka Allah akan merubah keadaan sebagaimana prasangka kepada Allah, seperti dalam firman Allah yang artinya: "Allah berada bersama prasangka hambanya." Dalam paham epistemologi 'irfani juga dinyatakan bahwa jika mendekat pada Allah, tentu Allah akan selalu menerima kehadiran, karena seseorang yang dekat dengan Allah akan mengadukan semua keluh kesah hanya kepada Allah dan Allah pun akan mengabulkan sesuatu yang dipanjatkan dalam istiqomah baik secara langsung maupun melalui perantara, seperti halnya "ilmu," dengan kebijakan apapun yang ditetapkan untuk meningkatkan kualitas pendidikan baik dalam persepsi pro maupun kontra, jika ingin meminta yang terbaik maka Allah akan mengabulkannya. Hanya saja bentuk usaha dan ikhtiar harus dimaksimalkan. Menurut paham burhani yang lebih mengutamakan prinsip-prinsip logika. Hal ini merupakan teori yang sangat berbeda dengan kedua teori

\footnotetext{
${ }^{44}$ Ibid

${ }^{45}$ A. Basiq Djalil, Logika (Ilmu Mantiq) (Jakarta: Kencana Prenada Media Group, 2010), 3-4
} 
Hasan Baharun, Saudatul Alawiyah: Pendidikan Full Day School...

di atas. Teori ini menyatakan bahwa jika menurut prinsip logika, adanya kebijakan FDS melatih otak dan fisik untuk menjadi sehat dan tajam. karena sesuatu hal yang dibiarkan berlama-lama tanpa fungsi dan manfaat akan mengalami perubahan dalam artian disini adalah "berkarat." Pernahkah disadar bahwa benda yang dikenal sebagai benda tajam seperti "pisau" akan mudah berkarat apabila tidak difungsikan dan manfaatkan sebagaimana manfaatnya? Begitu juga dengan otak yang akan menjadi tumpul karna hanya digunakan untuk beristirahat dan fisik yang tidak mau lelah sedikitpun. Padahal jika ingin meneladani Rasulullah yang memiliki waktu istirahat hanya sejenak saja, maka tidak akan ada pernyataan negatif terhadap kebijakan FDS.

\section{F. Daftar Pustaka}

Ahmad, Fadzila Azni. "Philosophical Underpinnings of Islamic Management Method: Worldview, Epistemology and Ontology." International Journal of Humanities and Social Science 2, no. 20 [Special Issue ] (2012).

Arifin, Muzayyin. Filsafat pendidikan Islam. Jakarta: Bumi Aksara, 2003.

Assegaf, Abd. Rachman. Filsafat Pendidikan Islam. Jakarta: PT. RajaGrafindo Persada, 2011.

Azhim, Ali Abdul. Epistemologi dan Aksiologi Ilmu Perspektif Al-Qur'an. Bandung: CV. Rosda, 1989.

Azram, M., "Epistemology An Islamic Perspective.” IIUM Engineering Journal 12, no. $5(2011)$

Az-Zuhri \& Nuraeni, Dhilla. "Pro dan Kontra Full Day School." NU ONLINE. 11 Agustus 2017.

Baharun, Hasan. "Pendidikan Anak Dalam Keluarga; Telaah Epistemologis." Pedagogik 3, no. 2 (2016): 96-107.

Baharun, Hasan. "Penilaian Berbasis Kelas Pada Pembelajaran Pendidikan Agama Islam Di Madrasah.” MODELING: Jurnal Program Studi PGMI 3, no. 2 (2016): 205

Baharun, Hasan. "Total Moral Quality: A New Approach for Character Education in Pesantren." Ulumuna 21, no. 1 (2017): 57-80.

Berthelon, Matias; Kruge, Diana \& Vienne, Veronica. "Longer School Schedules and Early Reading Skills: Effects from a Full-Day School Reform in Chile.” IZA DP no. 10282 (2016).

Dacholfany, M. Ihsan. "Reformasi Pendidikan Islam dalam Menghadapi Era Globalisasi: Sebuah Tantangan dan Harapan.” Jurnal Akademika 20, no. 01 (2015).

Djalil, A. Basiq. Logika (Ilmu Mantiq). Jakarta: Kencana Prenada Media Group, 2010. 
Echlos, Jhon. Kamus Inggris Indonesia. Jakarta: Gramedia,1996.

Efendy, Muhadjir. "Full Day School." (19 Agustus 2016), diakses pada 10 Oktober 2017, http://news.detik.com

Hasan, Nor. "Full Day School Model Alternative Pembelajaran PAI." Jurnal Pendidikan Tadris 1, no.1 (2006): 114-115.

Hawi, H. Akmal. "Sistem Full Day School di Sekolah Dasar Islam Terpadu (SDIT) Studi Kasus di Izzuddin Palembang.” Istinbath XIV, no. 16 (2015): 71-87.

Idusardi, "Sekolah Kehidupan Berbasis Realita (Kritik atas Gagasan Full Fay School 19 Agustus 2016), diakses pada 10 Oktober 2017, http://re-searchingines.com

Izzan, Ahmad \& Saehudin. Tafsir Pendidikan Studi Ayat-ayat Berdimensi Pendidikan. Banten: Pustaka Aufa Media, 2012.

Jurnalis. "Ini Kelebihan dan Kekurangan Full Day School." OKEZONE News. 09 Agustus 2016.

Kalimi, Logika (Teori dan Aplikasi). Jakarta: Gunung Persada GP Press, 2011.

Kamrani Buseri, Epistemologi Islam dan Reformasi Wawasan Pendidikan, 2015

Kamrani, Buseri. "Epistemologi Islam dan Reformasi Wawasan Pendidikan." Jurnal Ilmiah Peuradeun: International Multidisciplinary Journal 3, no.1 (2015).

Kristi, Ellen, "Bisakah Full Day School Menguatkan Karakter?" NU Jateng. 19 Juli 2017.

Mujahidin, Anwar. "Epistemologi Islam: Wahyu sebagai Sumber Ilmu," Ulumuna Jurnal Studi Keislaman 17, no.1 (2013).

Musliadi. "Epistemologi Keilmuan dan Islam (Kajian terhadap Pemikiran M.Amin Abdullah)." Jurnal Ilmiah Islam Futura 13, no.2 (2014).

Nasrah. "Pengetahuan Manusia dan Epistemologi Islam." e-USU-Jurnal Repository@2005 4, no. 2 (2008).

Nasution, Harun. Filsafat Islam. Jakarta: Bulan Bintang, 1978.

Nata, Abuddin. Metodology Study Islam. Jakarta: PT. RajaGrafindo Persada, 2000.

Negoro, R. Ady. "Persepsi Siswa Kelas XI tentang Program Full Day School di SMA Negeri 2 Sawahlunto. SKRIPSI. 2014.

Ratnaningsih, Enok. "Efektivitas Metode Drill dan Resitasi dalam Meningkatkan Pemahaman dan Keterampilan Siswa terhadap Hukum Bacaan Qolqolah dan $R o^{\prime}$ di SMP Negeri 1 Subang." Jurnal Pendidikan Agama Islam - Ta'lim 10, no.1 (2012): 79-94

Romadoni, Ahmad. "Perpres Full Day School Masuk Sinkronisasi (22 Agustus 2017)." Diakses pada 10 Oktober 2017. http://news.liputan6.com/read/3066764/perpresfull-day-school-masuk-tahap-sinkronisasi.

Setiyarini, Ida Nurhayati; Joyoatmojo, Sutarno \& Sunardi. "Penerapan Sistem Pembelajaran 'Fun dan Full Day School' untuk Meningkatkan Regiliutas Peserta Didik di SDIT AL ISLAM Kudus." JURNAL TEKNOLOGI PENDIDIKAN DAN PEMBELAJARAN 2, no. 2 (2014): 231-244 
Hasan Baharun, Saudatul Alawiyah: Pendidikan Full Day School...

Siregar, Lis Yulianti Syafrida. "Full Day School sebagai Penguatan Pendidikan Karakter." Jurnal Pendidikan dan Manajemen Islam 5, no.2 (2017).

Soleh, A. Khudori, "Model-model Epistemologi Islam,” Nitro PDF Professional, 2010.

Sujianto, Agus Eko. "Penerapan Full Day School dalam Lembaga Pendidikan Islam." Jurnal Pendidikan - Ta'lim 28, no. 02 (2015).

Yusuf, Kadar M. Tafsir Tarbawi (pesan-pesan Al-Qur'an tentang Penddikan). Jakarta: AMZAH, 2013. 